\title{
Foundations and Development of Modern Maternal and Child Health Services in Sokoto Area of Northern Nigeria
}

\author{
Labbo Abdullahi* \\ Department of History, Usmanu Danfodiyo University, Sokoto
}

*Corresponding Author: Labbo Abdullahi, Department of History, Usmanu Danfodiyo University, Sokoto

\begin{abstract}
The paper examines the institutionalization and development of modern maternal and child health $(\mathrm{MCH})$ services in Sokoto Area. It is a historical study that through content analysis of the existing literature and interviews, discusses the introduction of MCH services, the people's perception of and attitudes to the services as well as the subsequent acceptance and development of the services in the area. By so doing, the paper accounts for the historical root of the contemporary problems of MCH services in Sokoto Area; and present what can be learnt from that for the future. The findings of the study indicate that MCH services were initially abhorred by the Sokoto people and this was why the tardy progress of the services for nearly two decades after the introduction. However, after the services gained wider acceptance by the people, the Colonial Government failed to provide the needed facilities for the development of the services. Also, the Post-colonial Government was unable to counterchallenge most of the lingering left-over problems of MCH services up to 1986; when the general development of health care services was interrupted by the Structural Adjustment Programme (SAP). Finally, the paper presents some of the unabated challenges of MCH services that are still evident in the post-SAP period.
\end{abstract}

Keywords: Foundation, Development, Modern, Maternal and Child Health Service and Sokoto Area

\section{INTRODUCTION}

Maternal and Child Health (MCH) service comprises various programmes organized for the purpose of providing medical, health and welfare services for mothers and children. Its medical aspect includes pre-natal (ante-natal) and postpartum (post-natal) services as well as paediatric care in infancy, childhood and adolescence. Health and welfare services of $\mathrm{MCH}$ on the other hand comprise provision of health education to parents for taking care of children, family planning and provision of such nutritional substances as milk and orange juice for children. The targets for $\mathrm{MCH}$ are all women in their reproductive age group (15-45 years of age), infants (0-2 years), children (2-12 years) and even adolescents (12-16 years) (EPHTI, 2003: 1 and Mishra, nd). Generally, modern health care services were first introduced in southern Nigeria when a hospital was established in Lagos in 1863 (Schram, 1971: 103). With regard to MCH, the services were a later development in the whole British Empire. They began to be in 1920s when the high mortality rate of mothers and babies especially during childbirth became a predominant concern in the Empire. Efforts to promote obstetric and paediatric medical services in Nigeria commenced firstly in southern Nigeria in 1922 and the services were extended to the northern Nigeria in 1929 (Von Tol, 2007: 110-113). Precisely, modern MCH services began in the area of Sokoto in northern Nigeria in 1930 and thus, this paper begins from that period.

\subsection{Study Area}

Sokoto Area under study refers to the territories of the four emirates (Native Authorities) that were centrally administered under Sokoto Province by the British colonial officers. Presently, the territories constitute fifty-eight local government areas in the modern-day Sokoto, Kebbi and Zamfara States in northern Nigeria. The four emirates that made up the study area of this paper are: Sokoto, Gwandu, Argungu and Yauri. Sokoto Emirate was the largest of the emirates; making up the modern-day Sokoto and Zamfara States. The other three emirates are conflated together in Kebbi State (Blench et'al, 2006: 19-20).

\section{MeThOdologY}

This is a historical study that uses qualitative content analysis to analyse and interpret both primary and secondary sources on the history of maternal and child health services in Sokoto Area. The primary sources include archival materials that are deposited in Arewa House Archives Kaduna 
(AHAK), National Archives Kaduna (NAK) and Waziru Junaidu History and Cultural Bureau Archives, Sokoto (WJHCBAS). The information contained therein the materials was perused, analysed and interpreted. In addition, specific oral data on the subject matter was collected through interviews with relevant resource people. Secondary sources of data such as textbooks, journal articles, seminar papers, theses and dissertations that raise some issues on maternal and child health services were also studied, utilized and interpreted.

The study analyzed the data sourced from both primary and secondary sources through corroboration in order to arrive at informed opinions and judgement. This means that, materials produced in the distant past had been evaluated through comparison with contemporary ones and the data obtained through interviews. Moreover, secondary sources were evaluated through corroboration with primary sources to authenticate the former.

\section{FOUNDATIONS OF MCH SERVICES IN SOKOTO AREA, 1930-1946}

Throughout 1930s, the major provider of maternal and children health services in Sokoto Area was the Sokoto Hospital at Sokoto. The hospital offered ante-natal clinics which were only popular among the southern Nigerian women resident in the town. Indigenous Sokoto women were suspicious of the services and thus, refused to attend the clinics. The reason for the refusal of the services was that, they considered the hospital as a place for their children to be tamed to serve the interest of the colonial regime. Similarly, the fact that all the staff of the hospital were non-indigenes; Sokoto people became more suspicious of the services offered by the Yoruba, Igbo and Europeans, whom they perceived as agents of the Colonial Government. Moreover, all the staff of the hospital with exception of the Nursing Sister were males who were religiously and culturally considered unsuitable to perform medical examination on females (NAK/SOKPROF/5751D, 1940). Most importantly is that, the mistrust of the whole colonial regime and the existence of traditional maternal and child health services informed the construction of modern MCH services by the Sokoto people up to 1945. Consequently, the construction of the services was the major factor responsible for the adverse attitudes of Sokoto women to the services (Alkammawa, 2016). Detail is given in the succeeding heading.

Meanwhile, although the mistrust and suspicion continued, Sokoto women began to accept the services especially towards the closing year of 1930s and the beginning of the 1940s. For instance, by 1940 there were 472 women receiving ante-natal home services. Among them, 22 women gave birth to their babies in the hospital at Sokoto and consequently, a ward of the hospital was converted into maternity ward (NAK/SOKPROF/5751D, 1940). In addition, a new female ward and labour room as well as rooms for ante-natal and infant welfare clinics were constructed in the hospital in the same 1940. However, quite a number of Sokoto women continued to be apathetic to the hospital's antenatal care. But a number of post-natal cases were visited by the Nursing Sister through home visiting scheme in the year (NAK/SOKPROF/5751D, 1940 and ascertained by Alkammawa, 2016).

Moreover, the tardy progress of MCH services continued throughout 1941. The officers concerned realized that diplomacy was essential for the development of the services. Thus, the Nursing Sister and her staff emphasized on home visit to deliver ante-natal and post-natal services for those who did not attend the hospital (NAK/SOKPROF/5751D, 1941). The following table shows the figures for ante-natal and post-natal services among the Sokoto women by the Nursing Sister in 1941.

Table1. Showing the Ante-natal and Post-natal Services in Sokoto NA by 1941

\begin{tabular}{|l|l|l|l|}
\hline S/No & \multicolumn{1}{|c|}{ Service } & \multicolumn{1}{c|}{ Total Attendance } & \multicolumn{1}{c|}{ New Case } \\
\hline 1 & Ante-natal Examination at Clinic & 394 & 52 \\
\hline 2 & Anti-natal Visit to Compounds & 4,359 & 323 \\
\hline 3 & Post-natal Attendance at Clinic & Nil & Nil \\
\hline 4 & Post-natal Visit to Compounds & 995 & Nil \\
\hline
\end{tabular}

Source: NAK/SOKPROF/5751D/Medical Department Sokoto NA Annual Report for 1941

The above figures indicated that there was an improvement in the attendances as the people gradually became appreciative of modern maternal services because of their efficacy in curing illnesses and healing injuries. For instance, the figure for ante-natal home service in 1941 is 4,359 higher than the 472 recorded in 1940. However, the figure decreased in 1942; when only 258 pregnant women were 
visited. According to the Nursing Sister, all the visited cases were of the lower classes. The well to do women especially wives of the ruling class did not wish for the visits and were in most cases not visited. For instance, by the same year (1942) six babies were delivered in the Sultan's compound and none of them was reported to the Sister before and after the deliveries (NAK/SOKPROF/3108).

Up to 1943, when an important figure in person of Miss Cooper arrived in Sokoto as a Nursing Sister, there seemed to be very difficult task ahead to convince Sokoto women to become familiar with the modern ideas of $\mathrm{MCH}$ services. However, Cooper established personal relationships with them in order to win their confidence (AHAK/SNP/5/3/42). She was able to convince quite a number of women to appreciate modern ideas of maternal care. Cooper adopted Sokoto Dispensary as a station for the services since Sokoto women were suspicious of Sokoto Hospital. She was provided with a room at the dispensary where women were given treatments and thereafter, rest for a while instead of visiting them at homes. Cooper understood the locality and language of Sokoto; and thus, she was able to train some indigenous sisters as Female Community Attendants (FCAs). Pregnant Sokoto women were visited by FCAs who advised the former to call on them during labour. Although they had never done; after the birth, they invited FCAs for dressing the cord. Sokoto women began to be familiar with the services through the effort of FCAs under the supervision of Cooper and towards the end of 1943 a number of them attended even the hospitals' ante-natal clinic (Alkammawa, 2016; Waliyi, 2016 and Gero, 2016).

Meanwhile, Sokoto NA provided $£ 4,500$ in its 1944/1945 estimates for the establishment of a Women and Children Dispensary to advance MCH services (NAK/SOKPROF/3108). But the major hindrance to the services was lack of qualified female staff. Although Sokoto Dispensary was adopted to be equipped to the standard of the proposed Women and Children Dispensary, its services were delayed since there were no qualified female health workers to meet the requirements of $\mathrm{MCH}$ services. Consequently, indigenous midwives (Traditional Birth Attendants), locally called "Ar-bikai" (sing. arbiki) in Sokoto and Ungozomai (sing. Ungozoma) in areas like Kano, Zaria and Katsina were requested to participate in the services. Their cooperation to learn and apply modern skills in the exercise of their profession was sought (NAK/SOKPROF/3108). Their involvement could have been requested for two main reasons. Firstly, there would be experienced persons in the provision of the services; and secondly, their involvement may attract the confidence of the Sokoto women in the services. Although some Ar-bikai showed interest, unfortunately only four of them were selected for the training (NAK/SOKPROF/3108).

With regard to children health, the services began since 1930; but developed to the extent of dividing children health clinic at Sokoto Hospital into two sessions a week in 1939. One session intended for the indigenous Sokoto babies and the other for babies of southern Nigerians resident in Sokoto (NAK/SOKPROF/5751D, 1940). Moreover, in 1941 the child health clinics were re-organized as follows: Clinic I at the Sokoto Hospital for southerners, while Clinic II at Sokoto Dispensary for Sokoto people (NAK/SOKPROF/5751D, 1941). Clinic II was popular with Sokoto people and it was known as Baby Welfare Clinic in Sokoto Dispensary. In addition, there were home-visits by the Nursing Sister for the health and welfare of children (AHAK/SNP/5/3/42 and NAK/SOK PROF/ 7330). For instance, during Coopers' home visits to pregnant women, every child found with ailment was urged to attend the clinics where the daily attendances averaged 100 as at 1943 . Furthermore, about 20 marasmus babies attended the Sokoto Dispensary daily for fresh milk and orange juice. Cooper became over-burdened with the work of women and child care and a request for the posting of another Nursing Sister to the area was made. However, the request was not granted as the Colonial Government maintained that the posting of another Sister to Sokoto could only be possible after the Second World War (NAK/SOKPROF/3108). This is clear considering the fact that, quite a number of Medical Officers and Nursing Sisters were needed to look after the injured soldiers in the battlefields.

\section{Construction of Colonial MCH Services and the Challenge of Mistrust}

Generally, African construction of colonial health care service largely stemmed from the mistrust and suspicion of the colonizers by the colonized. Considering the roles of physicians and nursing sisters in the colonization and exploitation, it is natural that Sokoto people must have mistrusted colonial physicians, pharmacists, nursing sisters and their health facilities. Also, the disregard of Africans and African medical cultures by colonial health workers contributed significantly to the mistrust of the 
workers, themselves and their services by Africans. In the case of Sokoto, the mistrust was as a result of the end product of trade relations between the British and the Sokoto people, in which the former became the colonial masters of the latter. Likewise, the existence of Sokoto traditional medical practice, which the people of Sokoto believed can take care of their health care needs, as it did in the case of their forefathers, contributed in the irresolute acceptance of colonial health care services. Specifically, the same factors of mistrust and suspicion as well as the existence of traditional medical practice and or traditional birth attendants in particular, clouded the acceptance of modern maternal and child health services when they were introduced in the Sokoto Area.

Beginning with the mistrust and suspicion of colonial regime, majority of the Sokoto people were suspicious of hospitals, dispensaries and clinics as well as MCH services provided therein up to 1946. The suspicion was derived from their experiences starting from signing of treaties and the falsification of the contents of those treaties to the physical colonial conquest by the British (Argungu, 2016). It is based on this Fanon (1965: 121-135) claimed that, Africans perceived Europeans as having ulterior motive to dictate their conscience by the use of colonial drugs. Eventually, an appreciable number of people in Sokoto realized the efficacy of colonial drugs, but quite a number of them continued with their mistrust of the drugs (Argungu, 2016 and Sokoto, 2016). The suspicion increased with the disrespectful attitudes of European medical officers all over Africa. For example, British medical officers perceived Africans as sources of diseases and viewed African medical customs as savage. Thus, Africans perceived the attitudes as a manifestation of the British arrogance as well as desire to humiliate and relegate them to be inferior and British subjects (Keller, 2006: 29). Consequently, majority of the indigenous Sokoto women were never receptive to modern MCH services up to 1946.

Regarding the existence of traditional maternal and child health services, it is pertinent to note that, the history of traditional medicine in Africa is old as the history of Africans. In the process of mastering their continent, Africans developed healing traditions that were holistic and dynamics. Thus, Sokoto people had their perception and system of identifying, healing and preventing maternal and children illnesses and injuries before the modern ones were introduced by the British (Bui, 2015).

With respect to perception of maternal and child complications, like several other groups in Hausaland; Sokoto people had traditional beliefs in their causation. The causes of the complications in Sokoto cultural beliefs included supernatural, mystical, hereditary and genetic; all of which supernatural is the most conflicting belief with modern MCH services (Amzat and Razum, 2014: 3436). The beliefs were used in identifying the nature of any maternal and child complications as well as the guidelines to be observed for treatments. Unlike Sokoto people's conception, modern MCH services are provided on the basis of positivism, for instance, the "Germ Theory of Diseases, Parasitology and Bacteriology" (Campbell, 2007). MCH problems that are commonly associated with the spirits by the people in Sokoto Area include miscarriage, still-birth, poliomyelitis, smallpox and leprosy (Argungu, 2016). The conflicting beliefs in the causation of maternal and child health problems aggravated the ambivalent reception of colonial MCH services; and continue to be a major hitch to any such services in Sokoto Area. For example, polio immunization programme is one of such services that suffered setback because of the conflicting beliefs. For some Sokoto people, the cause of polio disease is the spirit, called Inna and thus, the disease is locally called Shan-Inna. According to the people's conception of the disease, its cure can be obtained from the same spirit.

Responding to maternal and children complications, Sokoto people developed a medical tradition which is as old as their history (Bunza, 1995: 35). Among the practitioners of the tradition are Traditional Birth Attendants (TBAs). Over the centuries, TBAs in Sokoto Area developed preventive and curative methods of maternal and child complications. Women and children were required to drink, bathe, or rub concoctions on their body for prevention and or treatment (Bunza, 1995: 48-53). Therefore, when modern $\mathrm{MCH}$ services were introduced by the British in the area, it became very difficult for Sokoto people (TBAs and patients) to abandon what was handed over to them by their forefathers. This explains why when TBAs were requested to be trained in and apply the modern techniques of $\mathrm{MCH}$ services in their enterprise, few of them cooperated. On the other hand, Sokoto women believed in the efficacy of TBAs to take care of their health needs as they did to their ancestors. On this ground, some Sokoto people and other African societies, continued with their irresolute attitudes to modern MCH services up to contemporary times. 


\section{Development of Maternal Child Health Services to 1960}

The major impetus to the development of MCH services was the assessment of the medical services provided by the Native Authorities in Sokoto Area. Thereafter the assessment, estimation was made in which a population of 20,000 people in Nigeria was assumed to have 2,140 children under the age of 2 years as well a birth rate of between 700 and 1,400 a year. Therefore, it was suggested that a MCH clinic was needed to provide services for the mothers and children in each of such area of 20,000 people. Native Authorities were encouraged to prioritize the provision of $\mathrm{MCH}$ services and the central Government agreed to provide supplements for the children's welfare (WJHCBAS/MED/2/ II/SOKPROF).

Consequently, majority of the dispensaries in Sokoto Area began to operate a $\mathrm{MCH}$ clinic. From the assessment to 1960, the major providers of the services became special clinics at General Hospitals in Sokoto and Gusau as well as Women and Children Welfare Clinic in Sokoto (Sokoto Native Authority); General Hospital Birnin-Kebbi in Birnin-Kebbi (Gwandu Native Authority) and Rural Health Centre in Argungu (Argungu Native Authority). In the case of Yauri Native Authority, there was no special clinic for MCH services throughout the colonial period (Qadi, 2016). In all the Native Authorities, the $\mathrm{MCH}$ services were augmented with the support of the United Nations International Children Emergency Fund (UNICEF) (AHAK/19/2/A12, Report for 1954).

In Argungu Native Authority, the RHC at Argungu began maternal and children welfare services in 1953. In the maternity section, the centre had female community attendants responsible for taking care of pregnant women through home-visits, and pregnant women were made to understand the significance of an after birth attendance at the centre for weekly check-up (NAK/SOKPROF/ TOU/22). Unfortunately, however; the services of the centre were restricted to Argungu town (NAK/SOKPROF/3108). In the case of children's well-being, Government supported by Rockfeller Grant and UNICEF provided dried-milk for children's welfare. The milk was first received and distributed among the mothers and headmasters of elementary schools in Argungu town (AHAK/19/02/A.14 Report for 1956). Subsequently, MCH services of the RHC were developed and extended to the rural areas of Argungu Native Authority. For instance, by 1956 there were 18,274 attendances at the centres' maternal clinic and a total of 12,000 home-visits were made by the staff of the centre (AHAK//SNP/19/23/A.395, Report for 1955-1956).

In Gwandu Native Authority, the Nursing Sister of Birnin-Kebbi Hospital superintended MCH services. Her services were appreciated to the extent that on a visit by a senior colonial medical officer to her clinic in 1956, he became impressed with the attendance by babies and commented as follows:

It is clear that very good work is being done here, the attendances and records comparing favourably with a rural clinic in the United Kingdom (NAK/SOKPROF/TOU/22).

Although rural areas of the Native Authority were somehow neglected in terms of maternal services, by 1957, there were children clinics at Gulumbe, Bunza and Kalgo villages. However, the daily attendance at the clinics was very poor; as it hardly reached 20 patients (NAK/SOKPROF/TOU/22). The poor attendances at the rural clinics might have been because of lack of enlightenment among rural populations.

In Sokoto Native Authority, the services at Women and Children Welfare Clinic (WCWC) were superintended by Miss Forester, the Nursing Sister of Sokoto General Hospital. The clinic took over from the Hospital, the burden of all MCH services since 1954 with good records. Thus, the major providers of such services in the Native Authority became Gusau General Hospital and WCWC. The institutions were provided with Government and UNICEF dried-milk which was distributed to children in major towns with less concern for rural areas (AHAK/SNP/19/23/A.395).

Finally, from 1958 through to 1960, all the MCH clinics in Sokoto Area were under the efforts of a number of female community attendants as well as trained TBAs, and superintended by Nursing Sisters. Although the clinics were only available in urban areas without adequate staff, their services continued to record good results in some major towns of Sokoto Area (AHAK/19/2/A.16, Report for 1958). 
Foundations and Development of Modern Maternal and Child Health Services in Sokoto Area of Northern Nigeria

\section{Post-Colonial Maternal and Child Health Services}

It is unfortunate that lack of proper and adequate neo-natal and post-natal care continued to contribute to the high rates of maternal and child mortalities in Sokoto Area after Nigerian independence. It is equally agonizing that, the high rates of infant and child mortalities continued to influence the culture of inducing families to pursue high birth rates to replace the dead ones (Bayawa, 2015). MCH services in the Area continued to be hampered by the inadequacy of staff; and thus, the high rates of maternal and child deaths continued unabated. Consequently, all the authorities concerned considered the situation to be a very challenging one and they prioritize $\mathrm{MCH}$ services by firstly, establishing a number of such clinics (AHAK/SNP/19/2/A.21, Report for 1963).

Principally up to 1970, the providers of MCH services in Sokoto Area were the General Hospitals in the Area, the RHC at Argungu and WCWC in Sokoto town. At the RHC and WCWC for instance, both curative and preventive $\mathrm{MCH}$ services were given. With regard to curative service, example is drawn from the services of the RHC, where in October, 1970 there were 3,168 attendances at the Infant and Child Health Clinics and 168 attendances with 13 deliveries at the Ante-natal Clinic (WJHCBAS/MED/28/11). From 1971 onwards, the number of MCH clinics increased and by 1973, there were 56 maternity beds in the hospitals in the Area as compared to none in the previous years (North-western State Statistical Hand Book, 1973: 143). The following tables show the maternity works by Argungu RHC, WCWC and the five General Hospitals in the Area by 1973.

Table2. Maternity Works by Argungu RHC and WCWC in 1973

\begin{tabular}{|l|c|c|c|c|c|c|c|c|}
\hline Clinic & \multicolumn{2}{|c|}{ Ante-natal Examination } & \multicolumn{2}{c|}{ Deliveries } & \multicolumn{4}{|c|}{ Results } \\
\hline & $\begin{array}{c}\text { Attendance at } \\
\text { Clinic }\end{array}$ & $\begin{array}{c}\text { Home } \\
\text { Visit }\end{array}$ & $\begin{array}{c}\text { At } \\
\text { Home }\end{array}$ & Clinic & $\begin{array}{c}\text { Still } \\
\text { Birth }\end{array}$ & $\begin{array}{c}\text { Live } \\
\text { Birth }\end{array}$ & $\begin{array}{c}\text { Maternal } \\
\text { Death }\end{array}$ & $\begin{array}{c}\text { Neo } \\
\text { Death }\end{array}$ \\
\hline RHC & 1,843 & 789 & 71 & 185 & 45 & 72 & 20 & 7 \\
\hline WCWC & 3,021 & 4,566 & 77 & 2 & Nil & 82 & Nil & Nil \\
\hline
\end{tabular}

Table3. Maternity Work at General Hospitals in Sokoto Area by 1973

\begin{tabular}{|l|l|l|l|}
\hline \multicolumn{1}{|c|}{ General Hospital } & \multicolumn{1}{c|}{ Admission } & \multicolumn{1}{c|}{ Maternity Attendance } & \multicolumn{1}{c|}{ Total Deliveries } \\
\hline 1. Birnin-Kebbi & 3,134 & 62,928 & 276 \\
\hline 2. Sokoto & 17,022 & 2,149 & 1,942 \\
\hline 3. Gusau & 2,856 & 4,696 & 819 \\
\hline 4. Gummi & 291 & 104 & 27 \\
\hline 5. Yauri & 1,778 & 4,094 & 266 \\
\hline
\end{tabular}

Source: North-western State Statistical Hand Book 1973, Ministry of Finance, Economic Planning Unit, Sokoto, 1973, pp. 1 \& 161

The tables show a significant increase in $\mathrm{MCH}$ services in Sokoto Area. Table 2 presented the MCH services of RHC and WCWC in the Area. Table 3 on the other hand, presented the figures of such services by the five General Hospitals in the Area. Moreover, from then onwards, the services continued to increase significantly. However, it is important to note that, in spite the development in the services, hundreds of women and children continued to die from complications of pregnancy, birth and puerperium. The major problem was that, in most cases $\mathrm{MCH}$ services were provided to a small proportion of mothers and children in the urban areas of Sokoto. The services were located mainly in Sokoto city and such towns like Argungu, Birnin-Kebbi, Gusau and Yelwa; while the larger proportion of the population was neglected in rural areas (Sokoto State Health Project, 1983: Chap. 2(7). The rural situation was revealed when a survey of Infant Mortality Rate (IMR) in rural areas of Sokoto was carried out by the Federal Office of Statistics in 1975. The survey put IMR at 178 deaths in each 1,000 infants in the rural areas. Thus, infant mortality in Sokoto continued to be a serious health problem (Sokoto State Health Project, 1983: Chap. 2(7).

In addition to the limited availability of $\mathrm{MCH}$ services in the rural areas, the high rate of maternal and child mortalities in Sokoto could be attributed to the low socio-economic status of women in the Area. This was very clear among the rural women who apart from the high rate of mortality, their culture of under-age marriage resulted in quite a number of Vesico Vaginal Fistula (VVF) cases (MAWCH, Annual Report, 1997: 1). Meanwhile, the number of MCH clinics kept on increasing in urban areas. For example, by 1985 there were $63 \mathrm{MCH}$ clinics in the Area as against 27 in 1979 (TechnoEconomic Survey, 1980: Chapter 10(16); Sokoto State Health Statistics of 1982, 1984: 2-9 and 
Sokoto State Health Statistics of 1985, 1987: 7). However, this development of MCH clinics was even in the urban areas seriously affected by the Structural Adjustment Programme (SAP) when Government cut off its expenditure on public health sector between 1986 and 1990.

\section{Post-SAP Era and the Challenges of Maternal and Child Health Services}

During the period after the SAP, the erstwhile institutional development of MCH in Sokoto Area was resuscitated; in which quite a number of both primary and secondary medical institutions were established. For example, Maryam Abacha Women and Children Hospital was established in 1996 in Sokoto town to provide secondary MCH services with special focus on VVF (MAWCH, Annual Report, 1997: 2). In addition, there is quite a number of new established General Hospitals, primary health centres and $\mathrm{MCH}$ clinics located in the cities; while, rural areas are serviced by poorly equipped and under-staffed dispensaries. Nevertheless, since the colonial period, MCH services in Sokoto Area have generally been affected by a number of challenges up to the contemporary time. Such challenges included inadequate accessibility and affordability to $\mathrm{MCH}$ services by the majority of the Sokoto population; little political prioritization of $\mathrm{MCH}$ services that resulted in the underfunding of such services; inadequacy and poor motivation of human resource for $\mathrm{MCH}$ services; cultural and socio-economic problems; illiteracy and lack of enlightenment; and recently, prevalence of drugs peddlers; and half-baked paediatricians and gynaecologists. Other challenges revolve around $\mathrm{MCH}$ staff that included lake of courtesy to patients, failure to turn up at work on time, absenteeism, failure to conduct proper patients' examinations and untimely treatment of patients. However, unequal rural-urban distribution of $\mathrm{MCH}$ services and inadequate staff that originated from colonial period; failure of pregnant and nursing mothers to have confidence in health advice by medical experts; insanitary environment and contamination of food and water; inadequate water for drinking and personal hygiene; living in sub-standard dwellings without space, ventilation and sunlight remain the major challenges of $\mathrm{MCH}$ services in the contemporary Sokoto Area. The challenges continue to cause incidences of air- and water-borne diseases that affect women and children; resulting into high rates of maternal and child mortalities. Not just that, but the conception that traditional medicine is efficacious than modern $\mathrm{MCH}$ services is still with the Sokoto women and it remains a serious challenge. The current practice is that, although, pregnant women attend to ante-natal and post-natal services of modern institutions, it is very common in Sokoto to see the relatives of ante- and postnatal patients who are admitted in hospitals "smuggle" in for them, the concoctions obtained from traditional birth attendants; and this is not peculiar to the rural women but urban dwellers, as well. Likewise quite a number of them have irresolute acceptance of immunization against child-killer diseases, especially poliomyelitis which they perceive to be caused by the spirit and can only be cured by the same spirit.

\section{CONCLUSION}

Conclusively, the paper discussed the foundation and development of modern $\mathrm{MCH}$ services in the Sokoto Area. Historical examination of the challenges in the provision of the services was made; and although, the institutions involved were very inadequate, the staff of the institutions did their very best in meeting the health care needs of women and children in the Area. However, the worst was unequal rural-urban distribution of the institutions and the lack of adequate personnel. For instance, the study discovered that, there were never five nursing sisters at a time in an area with over 2.5 million people throughout the colonial period. This is because even when all were available, the area was proposed to be served by four sisters; two in Sokoto Native Authority, and one in each of Gwandu and Argungu Native Authority. Thus, the nursing sisters available were always faced with an ever-increasing number of patients and obviously over-worked. This was undoubtedly the failure of the Colonial Government to provide a significant number of nursing sisters and train indigenous women for $\mathrm{MCH}$ services in the area. With regard to uneven rural-urban distribution, almost all the institutions and personnel were located in urban towns leaving the rest of the population to survive on traditional birth attendants. In the case of the post-colonial period, it was the failure of the indigenous government that the services were still at low pace up to 1970. However, between 1975 and 1985, MCH services began to be the top priorities of all the authorities concerned in which a number of $\mathrm{MCH}$ clinics were established. However, it was very unfortunate that, the development was suppressed by the SAP between 1986 and 1990. Although, the services received the attention of the authorities concerned in the post-SAP era, the major challenges of MCH services continued unabated with records of high 
rates of maternal and child mortalities. Thus, unless the challenges are over-come, maternal and child mortalities in Sokoto Area will remain with devastating effects. Finally, the article concludes by a saying 'if we could have but a generation of properly born, trained, educated, and healthy children, a thousand other problems of not only the states in Sokoto Area, but Nigeria as a whole would be vanished.

\section{REFERENCES}

\section{Informants}

[1] Sokoto Abdulkadir Isa, ( $7^{\text {th }}$ June, 2016). 71 years. Health Staff. Interview at his Residence, Sokoto Town, Sokoto State.

[2] Alkammawa Alhaji Ladan, (12 ${ }^{\text {th }}$ July, 2016). 97 years. Health Staff. Interview at his Residence in Alkammawa Area, Sokoto Town, Sokoto State.

[3] Argungu Ibrahim Musa, $\left(29^{\text {th }}\right.$ May, 2016). 72 years. Health Staff. Interview at his Residence Argungu Town, Kebbi State.

[4] Bayawa Malam Dangwaggo, (29 ${ }^{\text {th }}$ June, 2015). 96 years. Traditional Medical Practitioner. Interview at his Residence in Bayawa town of Augie Local Government, Kebbi State.

[5] Qadi Malam Ibrahim, (31 ${ }^{\text {st }}$ May, 2016). 73 years. Health Staff. Interview at his Residence, Yelwa Town. Yauri Local Government, Kebbi State.

[6] Bui Malam Na'Allah, (14 ${ }^{\text {th }}$ Jan., 2015). 87 years. Health Staff. Interview at his Residence in Argungu, Kebbi State.

[7] Gero Muhammad, (24 ${ }^{\text {th }}$ June, 2016). 97 years. Health Staff. Interview at his Residence in Goronyo Town, Sokoto State.

[8] Waliyi Muhammad Sambo, $\left(13^{\text {th }}\right.$ November, 2016). 79 years. Civil Servant. Interview at his Residence, Bazza Area, Sokoto Town, Sokoto State.

\section{Archival Materials}

[9] AHAK//SNP/19/23/A.395/Annual Report of Ministry of Health Northern Region of Nigeria for the Year $1955 / 1956$

[10] AHAK/19/02/A.14/ Provincial Annual Report 1956

[11] AHAK/19/2/A.16/Provincial Annual Report for 1958

[12] AHAK/19/2/A12/Provincial Annual Report for 1954

[13] AHAK/SNP/19/2/A.21/Provincial Annual Report for 1963

[14] NAK/SOKPROF/7330/Medical Field Units

[15] NAK/SOKPROF/3108/Training of Female Health Visitors/Nurses/Midwives/Community Attendants/ Sanitary Inspectors

[16] NAK/SOKPROF/5751D/Medical Department Sokoto, Annual Report 1940

[17] NAK/SOKPROF/5751D/Medical Department Sokoto N.A. Annual Report for 1941

[18] NAK/SOKPROF/TOU/22/Inspection Notes of M.O, S.M.O, Residents, etc.

[19] WJHCBAS/MED/2/II/SOKPROF/Development of Dispensary and Hospitals in Sokoto

[20] WJHCBAS/MED/28/11/Rural Health Centre at Argungu, 1971

\section{Official Documents}

[21] Maryam Abacha Women and Children Hospital (MAWCH), Annual Report, 1997.

[22] North-western State Statistical Hand Book 1973. (1973). Ministry of Finance, Economic Planning Unit, Sokoto.

[23] Sokoto State Health Project. (1983). Feasibility Report, Ministry of Economic Planning Sokoto, Sokoto State, Nigeria, MOCO Nigeria Limited.

[24] Sokoto State Health Statistics of 1982. (1984). Statistic Division; Ministry of Economic Planning, Sokoto, Nigeria.

[25] Sokoto State Health Statistics of 1985. (1987). Sokoto State of Nigeria, Statistic Division; Ministry of Economic Planning, Sokoto, Nigeria.

[26] Techno-Economic Survey. (1980). Sokoto State Ministry of Economic Planning, Sokoto, MOCO Nigeria Limited.

\section{Unpublished Materials}

[27] Blench, R. et'al (2006). "The Role of Traditional Rulers in Conflict Prevention and Mediation in Nigeria". 
Prepared for DFIF, Nigeria.

[28] Bunza, M. U. (1995). "The Contribution of Amirul Muminina Muhammad Bello (1781-1837) to the Development of Medicine in Nineteenth Century Hausaland. M.A. History, UDUS.

[29] Ethiopia Public Health Training Institute (EPHTI) (2003). "Maternal and Child Health". Lecture Notes for Health Science Students, University of Gonder.

\section{Published Materials}

[30] Amzat, J. And Razum, O. (2014). "Health, Disease, and Illness as Conceptual Tools". Medical Sociology in Africa, Switzerland: Springer International Publishing.

[31] Barnes, A.E. (2009).Making Headway: the Introduction of Western Civilization in Colonial Northern Nigeria. University of Rochester Press, USA, 2009.

[32] Fanon, F (1965).A Dying Colonialism, trans. by Haakon Chevalier (New York Grove).

[33] Keller, R.C. (2006). "Geographies of Power, Legacies of Mistrust: Colonial Medicine in the Global Present”. Historical Geography. Vol. 35, Geoscience Publications.

[34] Schram, R. (1971).A History of the Nigerian Health Services. Ibadan University Press, 1971.

[35] Vaughan, M. (1991). Curing their Ills Colonial Power and African Illness, Stanford University Press

[36] Von Tol D. (2007). "Mothers Babies, and the Colonial State: The Introduction of Maternal and Infant Welfare Services in Nigeria". Spontaneous Generation. University of Toronto.

\section{Internet Materials}

[37] Campbell W.C. (2012). “Germ Theory Calendar”. http://germtheorycalendar.com/db.aspx. accessed on the $15^{\text {th }}$ Nov. 2015.

[38] Mishra I.M. (nd). "Maternal and Child Health Programme". .slideshare.net/indramanimishra/maternal-andchild-programme. Accessed on 10/9/2016.

\section{AUTHORS' BIOGRAPHY}

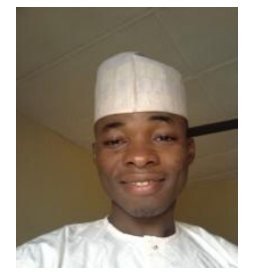

Labbo Abdullahi had a Ph.D Degree in History from Usmanu Danfodiyo University Sokoto, Nigeria. Currently he is a lecturer in the Department of History in the same University. He has special interest in social history of medicine; and he is published in a number of journals and have some chapters in edited books

Citation: Labbo Abdullahi. "Foundations and Development of Modern Maternal and Child Health Services in Sokoto Area of Northern Nigeria”. International Journal of History and Cultural Studies (IJHCS). vol 5, no. 1, 2018, pp. 1-9. doi: DOI: http://dx.doi.org/ 10.20431/2454-7654.0501001.

Copyright: (C) 2019 Authors. This is an open-access article distributed under the terms of the Creative Commons Attribution License, which permits unrestricted use, distribution, and reproduction in any medium, provided the original author and source are credited. 